\title{
Integrated Fertilizer Prescription Equations for Finger Millet (Eleusine coracana L.) Through Inductive Cum Targeted Yield Model on an Alfisol
}

\author{
P.K. Basavaraja*, H. Mohamed Saqeebulla and P. Dey \\ AICRP on STCR, Department of Soil Science and Agricultural Chemistry, College of \\ Agriculture, University of Agricultural Sciences, GKVK, Bengaluru, India - 560065 \\ *Corresponding author
}

\section{A B S T R A C T}

\begin{tabular}{l} 
Ke y w o r d s \\
Fertilizer \\
prescription \\
equations, STCR- \\
IPNS, Finger \\
millet, Yield \\
target. \\
\hline Article Info \\
$\begin{array}{l}\text { Accepted: } \\
\text { 26 June } 2017 \\
\text { Available Online: } \\
\text { 10 July } 2017\end{array}$
\end{tabular}

\section{Keywords}

Fertilizer IPNS, Finger millet, Yield Article Info
Studies on Soil Test Crop Response based Integrated Plant Nutrition System (STCR IPNS) were conducted adopting the Inductive cum Targeted yield model, on Alfisols of GKVK, Bengaluru, during 2008-2012 in order to develop fertilizer prescriptions through IPNS for the desired yield targets of finger millet crop. For calculating the four important basic parameters viz., nutrient requirement (NR), contribution of nutrients from soil $(\% \mathrm{CS})$, fertilizer $(\% \mathrm{CF})$ and organic matter $(\% \mathrm{C}-\mathrm{OM})$ were computed using the field experimental data. Making use of these basic parameters, the fertilizer prescription equations were developed under NPK alone and under IPNS for the desired yield targets of finger millet for a range of soil test values. The magnitude of response was higher under IPNS approach as compared to inorganics alone. The per cent reduction in NPK fertilizers under IPNS also increased with increasing soil fertility levels with reference to NPK. This could be achieved by integrated use of FYM with NPK fertilizers. Thus the Inductive cum Targeted yield model used to develop fertilizer prescription equations provides a strong basis for soil fertility maintenance consistent with high productivity and efficient nutrient management in "Precision Farming" for sustainable and enduring Agriculture.

\section{Introduction}

Nutrient absorption pattern of the plant and its efficient utilization of applied nutrients are necessary for obtaining the economically profitable returns. Fertilizer use is a major contributing factor for higher crop production in India. The fertilizer requirement of a crop largely depends on native soil fertility and hence, the prescription of doses should always be made by examining the relationships of soil test values with applied fertilizer doses and crop yield (Velayutham et al., 1976). Finger millet (Eleusine coracana L.) locally called as ragi in Karnataka, It is also known as poor man's food because of its long sustenance as it can be stored safely for many years without infestation by insects and pests. This millet can grow in almost all types of soils and climatic conditions including alkaline soils with $\mathrm{pH}$ as high as 11 and at an altitude of $2,500 \mathrm{~m}$ from sea level, with average annual rainfall ranging from 800 to $1,200 \mathrm{~mm}$. The low yield in millets under rainfed conditions was mainly attributed to poor nutrient status of soil, limited use of fertilizer either through chemical or organic sources coupled with insufficient moisture 
during crop growth period. Distortion in soil fertility and deterioration in soil health is due to indiscriminate and imbalanced use of fertilizers, which can be corrected only by proper use of manures and fertilizers based on the soil fertility evaluation. In recent years much emphasis has been given for use of fertilizer nutrients to produce adequate amount of high quality food. Such nutrient supply system helps for maintenance and possibly improvement of soil fertility for sustaining crop productivity on long term basis (Babalad, 1999).

Fertilizer recommendation based on soil test crop response correlation (STCR) concept are more quantitative, precise and meaningful because combined use of soil and plant analysis is involved in it. At this junction, the unique inductive cum targeted yield model of Ramamoorthy et al., (1967) is quite appropriate for determining a precise fertilizer prescription for finger millet crop. Hence, a present study has been taken on Alfisols of Southern Karnataka under dry land condition for finger millet crop to develop a STCR targeted yield equation with a farmer's friendly ready reckoner.

\section{Materials and Methods}

\section{Treatment structure, soil and plant analysis}

A field experiment was conducted with finger millet var.GPU-28 as test crop during 200809 and 2011-12 on Kandicpaleustalfs at Zonal Agriculture Research Station, GKVK, Bengaluru to develop the targeted yield equations by following the standard procedure as outlined by Ramamoorthy et al., 1967. Prior to test crop experimentation, the variation in the soil fertility was created by adopting the "Inductive cum Targeted Yield Model" (Ramamoorthy et al., 1967). The surface soil (0-20 cm deep) of the experimental field was red soil, well drained, sandy loam in texture with $\mathrm{pH} 6.13$, electrical conductivity $0.23 \mathrm{dSm}^{-1}$. The Initial soil organic carbon (OC \%) 0.51 per cent, available alkaline potassium permanganate $\left(\mathrm{KMnO}_{4}-\mathrm{N}\right)$ nitrogen, available Bray's phosphorus $\left(\mathrm{P}_{2} \mathrm{O}_{5}\right)$ and ammonium extractable potassium $\left(\mathrm{K}_{2} \mathrm{O}\right)$ were $181.38,90.85$ and $187.20 \mathrm{~kg} \mathrm{ha}^{-1}$ respectively. Fertility gradient experiment was conducted to develop wide variation in NPK fertility status in the same field by dividing experimental field into three rectangular strips $\left(\mathrm{L}_{1}, \mathrm{~L}_{2}\right.$ and $\left.\mathrm{L}_{3}\right)$. The needed variation in soil fertility levels was deliberately created by dividing the field into three equal strips $\left(\mathrm{L}_{1}\right.$, $\mathrm{L}_{2}$ and $\mathrm{L}_{3}$ ) which were applied with $1 / 2$ dose (37.5, 100 and $\left.100 \mathrm{~kg} \mathrm{NPK} \mathrm{ha}{ }^{-1}\right)$, standard dose $\left(75,200\right.$ and $\left.200 \mathrm{~kg} \mathrm{NPK} \mathrm{ha}{ }^{-1}\right)$ and double dose $\left(150,400\right.$ and $400 \mathrm{~kg}$ NPK ha $^{-1}$ ) in $\mathrm{L}_{1}, \mathrm{~L}_{2}$ and $\mathrm{L}_{3}$ strip respectively. An exhaustive crop of fodder maize was grown to enable the applied fertilizer nutrients to undergo transformation in the soil by plant and microbes. Fodder maize was harvested at 60 days after sowing (DAS) and recorded the fodder yield. Similarly soil samples were also collected and analysed for major nutrients to check the development of fertility gradient (Table 2).

This plot was used for conducting main experiment after establishment of fertility gradient. Each fertility strip was divided in to three blocks to impose three levels of FYM $\left(F_{1}-0.0, F_{2}-7.5\right.$ and $\left.F_{3}-15.0 \mathrm{tha}^{-1}\right)$. Before applying FYM and NPK fertilizers for each plot, soil samples $(0-20 \mathrm{~cm})$ from all these plots were collected and analysed for alkaline - $\mathrm{KMnO}_{4}-\mathrm{N}$ outlined by Subbaiah and Asija, 1956; Bray's-P and $\mathrm{NH}_{4} \mathrm{OAc}-\mathrm{K}$ method as described by Jackson (1973). The experiment was laid out in fractional factorial design comprising of 7 treated plots +1 control plot in each FYM blocks covering twenty one treated plots and three control treatments in each strips covering totally seventy two plots which comprised of sixty three treated plots 
and nine control plots and finger millet crop was tested with four levels of $\mathrm{N}(0,25,50$ and $\left.75 \mathrm{~kg} \mathrm{ha}^{-1}\right) \mathrm{P}_{2} \mathrm{O}_{5}\left(0,20,40\right.$ and $\left.60 \mathrm{~kg} \mathrm{ha}^{-1}\right)$ and $\mathrm{K}_{2} \mathrm{O}\left(0,15,25\right.$ and $\left.40 \mathrm{~kg} \mathrm{ha}^{-1}\right)$.

The IPNS treatments (NPK alone, FYM (7.5 t $\left.\mathrm{ha}^{-1}\right)+$ NPK and FYM $\left.\left(10 \mathrm{t} \mathrm{ha}^{-1}\right)+\mathrm{NPK}\right)$ were superimposed across the strips. Half dose of $\mathrm{N}$ fertilizer along with full dose of $\mathrm{P}$ and $\mathrm{K}$ were applied to finger millet at the time of sowing and remaining half dose of $\mathrm{N}$ was applied attillering stage as per package of practice. At harvest, grain and straw yield were recorded from all the plots, and expressed in $\mathrm{kg} \mathrm{ha}^{-1}$. Representative plant samples were collected from all the plots, washed thoroughly with running water followed by double distilled water. The plant samples including grain were then dried at $60^{\circ}$ $\mathrm{C}$ to attain a constant weight, ground and analysed for nitrogen, phosphorus and potassium contents by following standard procedures outlined by Jackson (1973) and total nutrient uptake was computed.

\section{Data computation}

Initial soil data, grain and straw yield, and nutrient uptake by finger millet crop were used for calculating the four important basic parameters viz., nutrient required to produce a quintal of grain yield (NR), contribution of nutrients from soil (\% CS), contribution of nutrients from fertilizers $(\% \quad \mathrm{CF})$ and contribution of nutrients from organic matter (C-OM) using following formulae (Ramamoorthy et al., 1967).

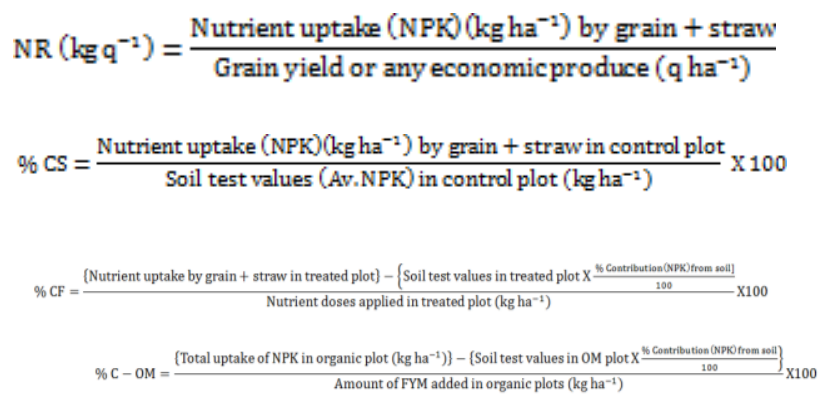

These basic parameters were transformed into simple, workable fertilizer adjustment equations for calculating specific yield target based on soil test values by following the procedure of Ramamoorthy et al., (1967).

\section{Results and Discussion}

\section{Fodder yield and soil test values of gradient} experiment

Maize had been found to develop fertility gradient for the three major nutrient elements in the experimental strips because of inherent capacity of maize, as an exhaustive crop, which leads to mining of plant available nutrients leaving relatively consistent nutrient sink in soil resulting a fine tuned fertility gradient.

The first year gradient experiment data revealed that the fodder yield varied from 7.16 to $8.56 \mathrm{t} \mathrm{ha}^{-1}$ in low to high fertility strip. Whereas, in second year lowest fodder yield (28.75 $\mathrm{t} \mathrm{ha}^{-1}$ ) was recorded in $\mathrm{L}_{1}$ strip and the highest yield (44.31 t ha ${ }^{-1}$ ) was recorded in $\mathrm{L}_{3}$ strip. The soil status at harvest clearly depicted (Table 1), that fertility gradient was developed from $L_{1}$ to $L_{3}$.

Low yield of fodder maize was mainly due to moisture constraints but NPK fertilizer application was one of the major factor for variation in fodder yield.

The increase in fresh yield of forage under different dose fertilizer application can be attributed to the positive effect of fertilizer and efficiency of these fertilizers on all the parameters in this study. These findings are in conformity with the findings of Ellis et al., (1956) and Singh et al., (1992).

The soil data at harvest of fodder maize varied from 59.47 to $81.38 \mathrm{~kg} \mathrm{~N} \mathrm{ha}^{-1}, 75.40$ to $90.85 \mathrm{~kg} \mathrm{P}_{2} \mathrm{O}_{5} \mathrm{ha}^{-1}$ and 175.20 to $187.20 \mathrm{~kg}$ $\mathrm{K}_{2} \mathrm{O} \mathrm{ha}^{-1}$ in the first year. Similarly, in the 
second year, soil chemical properties after the harvest of maize crop indicated the increased fertility status from $L_{1}, L_{2}$ and $L_{3}$ strip, where available nitrogen increased from 288.00 to $599.00 \mathrm{~kg} \mathrm{~N} \mathrm{ha}^{-1}$ strip, the available phosphorus increased from $61.32 \mathrm{~kg} \mathrm{P}_{2} \mathrm{O}_{5} \mathrm{ha}^{-1}$ $\left(\mathrm{L}_{1}\right)$ to $125.00 \mathrm{~kg} \mathrm{P}_{2} \mathrm{O}_{5} \mathrm{ha}^{-1}\left(\mathrm{~L}_{2}\right)$ and available potassium from $85.02 \mathrm{~kg} \mathrm{ha}^{-1}\left(\mathrm{~L}_{1}\right)$ to 220.05 $\mathrm{kg} \mathrm{ha}^{-1}\left(\mathrm{~L}_{3}\right)$ strips. The increase in availability of $\mathrm{N}, \mathrm{P}$ and $\mathrm{K}$ status of soil was due to graded levels of fertilizer application, which created a fertility gradient in the respective strips. However, even though $\mathrm{P}$ was not applied, gradient was developed in $\mathrm{P}$ levels from $\mathrm{L}_{1}$ to $\mathrm{L}_{3}$, mainly due to residual $\mathrm{P}$ level from the earlier gradient experiment in the same yield In the present study all the needed soil fertility gradient $\left(\mathrm{L}_{1}, \mathrm{~L}_{2}\right.$ and $\left.\mathrm{L}_{3}\right)$ was deliberately created in the same field by growing exhaustive maize crop for 60 days the result in conformity with the findings of Santhi et al., (2011). Thamaraiselvi et al., (2012) reported increased soil total $\mathrm{N}$ and available phosphorus due to FYM application.

\section{Initial available NPK status, grain yield and nutrient uptake}

The data on soil available nutrient status was depicted in table 3 . The initial soil test values revealed that the available nitrogen ranged from 65.73 to 184.67 and 111.72 to $410.56 \mathrm{~kg}$ $\mathrm{N} \mathrm{ha}{ }^{-1}$ in I and II year respectively. The available phosphorus in strip I was lowest (40.81 $\mathrm{kg} \quad \mathrm{P}_{2} \mathrm{O}_{5} \quad \mathrm{ha}^{-1}$ ) and highest was observed in strip III (455.20 kg $\left.\mathrm{P}_{2} \mathrm{O}_{5} \mathrm{ha}^{-1}\right)$ in $1^{\text {st }}$ year, whereas in second year, lowest and highest $\left(38.70\right.$ and $\left.189.01 \mathrm{~kg} \mathrm{ha}^{-1}\right) \mathrm{P}_{2} \mathrm{O}_{5}$ content was recorded in strip I. The mean $\mathrm{NH}_{4} \mathrm{OAc}-\mathrm{K}_{2} \mathrm{O}$ content in soil ranged from 128.78 to 286.35 in first year, whereas in second year mean available $\mathrm{K}$ ranged from 80.11 to $286.35 \mathrm{~kg} \mathrm{~K}_{2} \mathrm{O} \mathrm{ha}^{-1}$.

The range and mean values indicated that the finger millet grain yield ranged from 864.00 $\mathrm{kg} \mathrm{ha}^{-1}$ in absolute control to $6182.00 \mathrm{~kg} \mathrm{ha}^{-1}$ in strip III where 75:40:40 $\mathrm{kg}$ NPK $\mathrm{ha}^{-1}+$ FYM @ $7.5 \mathrm{t} \mathrm{ha}^{-1}$ was applied in first year. Whereas, in second year same trend was followed with slight increase in grain yield in absolute control (1148.00 kg ha $\left.{ }^{-1}\right)$ and treated plot (75:60:25 kg NPK ha ${ }^{-1}$ ) recorded 6552.00 $\mathrm{kg} \mathrm{ha}^{-1}$ grain yield.

\section{Nutrient uptake by finger millet}

Application of adequate amount of nutrients is a prerequisite for exploiting genetic potential of any crop. Across fertility gradient and FYM levels, application of different levels of $\mathrm{N}$ caused significant changes in uptake of $\mathrm{N}$ in both the year of study.

The N uptake in Strip I, II and III varied from 11.49 to $70.95,19.50$ to 71.90 and 33.67 to $102.60 \mathrm{~kg} \mathrm{~N} \mathrm{ha}^{-1}$ and 28.05 to $167.21,56.90$ to 217.35 and 39.43 to $456.93 \mathrm{~kg} \mathrm{~N} \mathrm{ha}^{-1}$ in $1^{\text {st }}$ and $2^{\text {nd }}$ year of study, respectively. The maximum nitrogen uptake was associated with the highest level of $\mathrm{N}$ applied plots but the minimum values were associated with the no $\mathrm{N}$ input. The phosphorus uptake by finger millet varied from 1.87 to $19.05 \mathrm{~kg} \mathrm{ha}^{-1}$ and $\mathrm{K}$ uptake from 12.59 to $125.38 \mathrm{~kg} \mathrm{ha}^{-1}$ in first year of study. In second year, the $\mathrm{P}$ uptake ranged from 13.56 to $101.17 \mathrm{~kg} \mathrm{ha}^{-1}$ and $\mathrm{K}$ uptake ranged from 57.33 to $723.77 \mathrm{~kg} \mathrm{ha}^{-1}$. The application of higher levels of $\mathrm{P}$ and $\mathrm{K}$ fertilizers will influence on the uptake of $\mathrm{P}$ and $\mathrm{K}$ by finger millet crop.

The magnitude of $\mathrm{P}$ and $\mathrm{K}$ uptake due to application of different levels of $\mathrm{P}$ and $\mathrm{K}$ followed same trend as that of yield. The existence of operational range of soil test values for available $\mathrm{N}, \mathrm{P}_{2} \mathrm{O}_{5}$ and $\mathrm{K}_{2} \mathrm{O}$ status in the present investigation was clearly depicted from the initial soil available nutrient status and variations in the grain yield of finger millet and NPK uptake, which is a prerequisite for calculating the basic parameters and developing fertilizer prescription equations for calibrating the 
fertilizer doses for specific yield target of dry land finger millet. Uma Devi (2005) reported similar existence of operational ranges of available $\mathrm{N}, \mathrm{P}$ and $\mathrm{K}$ for carrot crop on Ultisol.

\section{Basic parameters}

In the targeted yield model, the basic parameters for developing fertilizer prescription equations for dry land finger millet are nutrient requirement (NR) in $\mathrm{kg}$ per quintal of grain, per cent contribution of available NPK from soil (\% CS), fertilizers $(\% \mathrm{CF})$ and organic manure (\% C-OM). By making use of basic data's obtained from the main experiment viz., Initial soil test values for available $\mathrm{N}, \mathrm{P}_{2} \mathrm{O}_{5}$ and $\mathrm{K}_{2} \mathrm{O}$, doses of fertilizer $\mathrm{N}, \mathrm{P}_{2} \mathrm{O}_{5}$ and $\mathrm{K}_{2} \mathrm{O}$ applied, the grain yield of finger millet, total uptake of $\mathrm{N}, \mathrm{P}_{2} \mathrm{O}_{5}$ and $\mathrm{K}_{2} \mathrm{O}$, the basic parameters viz. NR, CS, $\mathrm{CF}$ and $\mathrm{C}-\mathrm{OM}$ were computed. Nutrient requirement per quintal of finger millet grain production were observed to be 2.764 and 3.587, 0.488 and 1.233 and 2.546 and 6.478 $\mathrm{kg} \mathrm{N}, \mathrm{P}_{2} \mathrm{O}_{5}$ and $\mathrm{K}_{2} \mathrm{O}$ in first and second year respectively.

The per cent contribution of nutrients from soil (CS) to the total uptake was computed from the absolute control plots and it expresses the capacity of the crop to extract nutrients from the soil. In the present study contribution of nutrients as estimated from soil and fertilizer sources was higher (35.856\%, 58.812\%, $90.257 \%$ and $37.547 \%$, $48.984 \%, 155.787 \% \mathrm{~N}, \mathrm{P}_{2} \mathrm{O}_{5}$ and $\mathrm{K}_{2} \mathrm{O}$, respectively) in second year compared to first year $(14.483 \%, 10.423 \%, 19.126 \%$ and $30.267,30.476$ and $109.329 \% \mathrm{~N}, \mathrm{P}_{2} \mathrm{O}_{5}$ and $\mathrm{K}_{2} \mathrm{O}$, respectively). These results indicate that nutrient contribution from fertilizer sources was greater than that from the soil source for both the years. The findings are closely accorded with those reported by Ray et al., (2000) and Meena et al., (2001). Similar trend of nutrient requirement for $\mathrm{N}, \mathrm{P}_{2} \mathrm{O}_{5}$ and $\mathrm{K}_{2} \mathrm{O}$ were reported by Smitha et al., (2010) for Cabbage. Among the three major nutrients $\mathrm{K}_{2} \mathrm{O}$ requirement is the highest, followed by $\mathrm{N}$ and $\mathrm{P}_{2} \mathrm{O}_{5}$. It is interestingly noted that contribution of $\mathrm{K}_{2} \mathrm{O}$ for finger millet (Table 4) was observed to be more than $100 \%$ $(155.78 \%)$.

This high value of $\mathrm{K}$ could be due to the interaction effect of higher doses of $\mathrm{N}, \mathrm{P}$ and the primary effect of starter $\mathrm{K}$ doses in the treated plots, which might have caused the release of soil potassium form, resulting in the higher uptake from the native soil sources by the crop (Ray et al., 2000). The contribution from fertilizers was higher than from the soil for all the three nutrients. The contribution of nutrients towards the growth of the crop was higher from fertilizers than that of soil for all the three nutrients $\left(\mathrm{N}, \mathrm{P}_{2} \mathrm{O}_{5}\right.$ and $\left.\mathrm{K}_{2} \mathrm{O}\right)$.

The per cent contribution from the organic manures (C-OM) to the total uptake was computed from the organic manure applied plots $\left(\mathrm{F}_{1} @ 7.5 \mathrm{t} \mathrm{ha}^{-1}\right.$ and $\left.\mathrm{F}_{2} @ 10 \mathrm{t} \mathrm{ha}^{-1}\right)$. The first year data showed that 19.23, 9.92, 40.47 per cent of $\mathrm{N}, \mathrm{P}_{2} \mathrm{O}_{5}$ and $\mathrm{K}_{2} \mathrm{O}$ towards the total uptake by finger millet. Whereas, in second year of study the per cent of $\mathrm{N}, \mathrm{P}_{2} \mathrm{O}_{5}$ and $\mathrm{K}_{2} \mathrm{O}$ was $0.348,0.018$ and 0.887 respectively. The results of the study are in conformity with the work of Vijayalakshmi (2008) for radish and Santhi et al., (2011) for beetroot on Typic haplustalf. The findings also corroborated with the findings of Santhi et al., (2002) and Saranyaet al., (2012).

\section{Fertilizer prescription equations for finger millet crop under dry land}

Soil test based fertilizer prescription equations for desired yield target of finger millet were formulated by relating the basic parameters obtained from the main experiment.

Fertilizer prescription targeted yield equations were developed as follows by further simplification of this relation. 
Table.1 Graded dose of fertilizers applied, fodder yield obtained and soil test values after Harvest of maize crop in gradient experiment

\begin{tabular}{|c|c|c|c|c|c|c|c|c|c|c|c|}
\hline \multirow[t]{2}{*}{ Strip } & \multirow{2}{*}{\multicolumn{3}{|c|}{$\begin{array}{l}\text { Level of } \\
\text { fertilizers }\end{array}$}} & \multicolumn{4}{|c|}{$\begin{array}{l}\text { Input applied } \\
\quad\left(\mathrm{kg} \mathrm{ha}^{-1}\right)\end{array}$} & \multirow{2}{*}{$\begin{array}{l}\text { Fodder } \\
\text { Yield } \\
\left(\mathrm{t} \mathrm{ha}^{-1}\right)\end{array}$} & \multicolumn{3}{|c|}{$\begin{array}{c}\text { Soil test values after } \\
\text { harvest } \\
\left(\mathrm{kg} \mathrm{ha}^{-1}\right)\end{array}$} \\
\hline & & & & FYM & $\mathrm{N}$ & $\mathrm{P}_{2} \mathrm{O}_{5}$ & $\mathrm{~K}_{2} \mathrm{O}$ & & $\mathrm{N}$ & $\mathrm{P}_{2} \mathrm{O}_{5}$ & $\mathrm{~K}_{2} \mathrm{O}$ \\
\hline \multicolumn{12}{|c|}{ First year } \\
\hline $\mathrm{L}_{1}$ & $\mathrm{~N}_{0}$ & $\mathrm{P}_{0}$ & $\mathrm{~K}_{0}$ & 3.75 & 37.5 & 0.00 & 100 & 7.16 & 59.47 & 75.40 & 175.20 \\
\hline $\mathrm{L}_{2}$ & $\mathrm{~N}_{1} *$ & $\mathrm{P}_{1} *$ & $\mathrm{~K}_{1}$ * & 7.50 & 75.00 & 0.00 & 200 & 8.30 & 68.86 & 78.60 & 182.40 \\
\hline $\mathrm{L}_{3}$ & $\mathrm{~N}_{2}$ & $\mathrm{P}_{2}$ & $\mathrm{~K}_{2}$ & 15.00 & 150.00 & 0.00 & 400 & 8.56 & 81.38 & 90.85 & 187.20 \\
\hline \multicolumn{12}{|c|}{ Second year } \\
\hline $\mathrm{L}_{1}$ & $\mathrm{~N}_{0}$ & $\mathrm{P}_{0}$ & $\mathrm{~K}_{0}$ & 3.75 & 18.75 & 0.00 & 100 & 28.75 & 288.00 & 61.32 & 85.12 \\
\hline $\mathrm{L}_{2}$ & $\mathrm{~N}_{1} *$ & $\mathrm{P}_{1} *$ & $\mathrm{~K}_{1} *$ & 7.50 & 37.50 & 0.00 & 200 & 39.35 & 373.00 & 88.85 & 164.89 \\
\hline $\mathrm{L}_{3}$ & $\mathrm{~N}_{2}$ & $\mathrm{P}_{2}$ & $\mathrm{~K}_{2}$ & 15.00 & 75.00 & 0.00 & 400 & 44.31 & 599.00 & 125.0 & 220.05 \\
\hline
\end{tabular}

* Recommended dose of nutrients to fodder maize

Table.2 Treatment structure

\begin{tabular}{ccccccc}
\hline \multirow{2}{*}{ No. } & \multicolumn{3}{c}{ Treatment combination } & \multicolumn{3}{c}{ Levels of nutrients $\left(\mathrm{kg} \mathrm{ha}^{-1}\right)$} \\
\cline { 2 - 6 } & $\mathrm{N}$ & $\mathrm{P}_{2} \mathrm{O}_{5}$ & $\mathrm{~K}_{2} \mathrm{O}$ & $\mathrm{N}$ & $\mathrm{P}_{2} \mathrm{O}_{5}$ & $\mathrm{~K}_{2} \mathrm{O}$ \\
\hline 1 & 0 & 0 & 0 & 0 & 0 & 0 \\
2 & 0 & 0 & 0 & 0 & 0 & 0 \\
3 & 0 & 0 & 0 & 0 & 0 & 0 \\
4 & 0 & 2 & 1 & 0 & 40 & 15 \\
5 & 1 & 1 & 1 & 25 & 20 & 15 \\
6 & 1 & 1 & 2 & 25 & 20 & 25 \\
7 & 1 & 2 & 1 & 25 & 40 & 15 \\
8 & 1 & 2 & 2 & 25 & 40 & 25 \\
9 & 2 & 0 & 2 & 50 & 0 & 25 \\
10 & 2 & 1 & 1 & 50 & 20 & 15 \\
11 & 2 & 1 & 2 & 50 & 20 & 25 \\
12 & 2 & 2 & 0 & 50 & 40 & 0 \\
13 & 2 & 2 & 1 & 50 & 40 & 15 \\
14 & 2 & 2 & 3 & 50 & 40 & 40 \\
15 & 2 & 2 & 2 & 50 & 40 & 25 \\
16 & 2 & 3 & 2 & 50 & 60 & 25 \\
17 & 2 & 3 & 3 & 50 & 60 & 40 \\
18 & 3 & 1 & 1 & 75 & 20 & 15 \\
19 & 3 & 1 & 2 & 75 & 20 & 25 \\
20 & 3 & 2 & 1 & 75 & 40 & 15 \\
21 & 3 & 2 & 3 & 75 & 40 & 40 \\
22 & 3 & 3 & 1 & 75 & 60 & 15 \\
23 & 3 & 3 & 2 & 75 & 60 & 25 \\
24 & 3 & 3 & 3 & 75 & 60 & 40 \\
\hline
\end{tabular}

* FYM levels: $\mathrm{F}_{0}-0 \mathrm{tha}^{-1}, \mathrm{~F}_{1}-7.5 \mathrm{t} \mathrm{ha}^{-1}$ and $\mathrm{F}_{2}-15 \mathrm{t} \mathrm{ha}^{-1}$ 
Table.3 Pre-sowing soil available NPK content, grain yield and

NPK uptake by finger millet crop

\begin{tabular}{|c|c|c|c|c|c|c|c|c|c|c|}
\hline \multirow{2}{*}{ Year } & \multirow{2}{*}{ Strip } & & \multicolumn{3}{|c|}{ Soil test values $\left(\mathrm{kg} \mathrm{ha}^{-1}\right)$} & \multicolumn{2}{|c|}{ Finger millet yield $\left(\mathrm{kg} \mathrm{ha}^{-1}\right)$} & \multicolumn{3}{|c|}{ Uptake $\left(\mathrm{kg} \mathrm{ha}^{-1}\right)$} \\
\hline & & & $\mathrm{KMnO}_{4}-\mathrm{N}$ & Bray's $\mathbf{P}_{2} \mathbf{O}_{5}$ & $\mathrm{NH}_{4} \mathrm{OAc}-\mathrm{K}_{2} \mathrm{O}$ & Grain yield & Straw yield & $\mathbf{N}$ & $\mathbf{P}$ & $\mathbf{K}$ \\
\hline \multirow{9}{*}{$\mathbf{I}$} & \multirow{3}{*}{$\mathbf{I}$} & Min & 102.50 & 40.81 & 96.00 & 864.00 & 455.00 & 11.49 & 1.87 & 12.59 \\
\hline & & Max & 184.67 & 112.00 & 193.20 & 4000.00 & 2473.00 & 70.95 & 10.60 & 70.99 \\
\hline & & Mean & 141.60 & 75.30 & 128.78 & 2664.67 & 1511.92 & 42.87 & 7.53 & 52.18 \\
\hline & \multirow{3}{*}{ II } & Min & 78.25 & 159.53 & 146.40 & 1273.00 & 655.00 & 19.50 & 3.89 & 28.75 \\
\hline & & Max & 122.15 & 261.14 & 291.60 & 4273.00 & 2155.00 & 71.90 & 13.82 & 84.86 \\
\hline & & Mean & 102.22 & 209.25 & 203.88 & 3182.75 & $\mathbf{1 6 3 8 . 5 8}$ & 50.60 & 9.67 & 61.61 \\
\hline & \multirow{3}{*}{ III } & Min & 65.73 & 214.52 & 200.40 & 1909.00 & 1000.00 & 33.67 & 6.26 & 42.65 \\
\hline & & Max & 75.00 & 455.20 & 392.40 & 6182.00 & 3318.00 & 102.60 & 19.05 & 125.38 \\
\hline & & Mean & 97.14 & 351.78 & 286.35 & 3255.08 & 2205.46 & 61.24 & 10.78 & 82.55 \\
\hline \multirow{9}{*}{ II } & \multirow{3}{*}{ I } & Min & 111.72 & 38.70 & 56.80 & 1148.00 & 220.50 & 28.05 & 13.56 & 57.33 \\
\hline & & Max & 367.08 & 189.01 & 120.00 & 5082.00 & 938.30 & 167.21 & 60.16 & 287.68 \\
\hline & & Mean & 280.72 & 120.80 & 80.11 & 3310.00 & 590.90 & 85.87 & 34.52 & 180.51 \\
\hline & \multirow{3}{*}{ II } & Min & 230.00 & 72.68 & 109.20 & 1471.00 & 328.70 & 56.90 & 18.20 & 93.39 \\
\hline & & Max & 331.97 & 180.30 & 334.80 & 5707.00 & 1079.90 & 217.35 & 56.39 & 351.11 \\
\hline & & Mean & 279.91 & 127.71 & 184.62 & 3805.00 & 717.80 & 116.33 & 37.91 & 216.54 \\
\hline & \multirow{3}{*}{ III } & Min & 224.50 & 81.20 & 108.00 & 1287.00 & 413.00 & 39.43 & 18.22 & 109.02 \\
\hline & & Max & 410.56 & 158.30 & 495.60 & 6552.00 & 2322.10 & 456.93 & 101.17 & 723.77 \\
\hline & & Mean & 305.66 & 117.60 & 264.77 & 4417.00 & 1621.90 & 239.79 & 70.92 & 403.31 \\
\hline
\end{tabular}

Table.4 Nutrient requirement and contribution of nutrients from soil, fertilizers and

Organic matter for finger millet

\begin{tabular}{|l|c|c|c|c|c|c|}
\hline \multirow{2}{*}{ Parameters } & \multicolumn{3}{|c|}{ Basic data } \\
\cline { 2 - 7 } & \multicolumn{2}{|c|}{$\mathbf{N}$} & \multicolumn{2}{c|}{$\mathbf{P}_{\mathbf{2}} \mathbf{O}_{\mathbf{5}}$} & \multicolumn{2}{c|}{$\mathbf{K}_{\mathbf{2}} \mathbf{O}$} \\
\cline { 2 - 7 } & I Year & II Year & I Year & II Year & I Year & II Year \\
\hline Nutrient requirement (NR) $\left(\mathrm{kg} \mathrm{q}^{-1}\right)$ & 2.764 & 3.587 & 0.488 & 1.223 & 2.546 & 6.478 \\
\hline Contribution from soil (CS) (\%) & 14.483 & 35.856 & 10.423 & 58.812 & 19.126 & 90.257 \\
\hline Contribution from fertilizers (CF) (\%) & 30.287 & 37.547 & 30.476 & 48.984 & 109.329 & 155.787 \\
\hline Contribution from organic matter - (C-OM) (\%) & 19.235 & 0.348 & 9.924 & 0.018 & 40.478 & 0.887 \\
\hline
\end{tabular}

Table.5 Ready reckoner for dryland finger millet for a yield target of $35 \mathrm{q} \mathrm{ha}^{-1}$

\begin{tabular}{|c|c|c|c|c|c|c|c|c|c|c|c|}
\hline \multicolumn{3}{|c|}{ 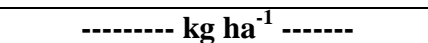 } & \multicolumn{3}{|c|}{ Without FYM } & \multicolumn{3}{|c|}{ With 7.5 t FYM ha ${ }^{-1}$} & \multicolumn{3}{|c|}{ Reduction over NPK alone (\%) } \\
\hline $\begin{array}{c}\mathrm{STV} \\
\mathrm{KMnO}_{4}-\mathrm{N}\end{array}$ & $\begin{array}{l}\text { STV } \\
\mathrm{P}_{2} \mathrm{O}_{5}\end{array}$ & $\begin{array}{l}\text { STV } \\
\mathrm{K}_{2} \mathrm{O}\end{array}$ & $\begin{array}{l}\text { F. Rq. } \\
\mathbf{N}\end{array}$ & $\begin{array}{l}\text { F. Rq. } \\
\mathrm{P}_{2} \mathrm{O}_{5}\end{array}$ & $\begin{array}{c}\text { F. Rq. } \\
\mathrm{K}_{2} \mathrm{O}\end{array}$ & $\begin{array}{l}\text { F. Rq. } \\
\mathbf{N}\end{array}$ & $\begin{array}{l}\text { F. Rq. } \\
\mathrm{P}_{2} \mathrm{O}_{5}\end{array}$ & $\begin{array}{c}\text { F. Rq. } \\
\mathrm{K}_{2} \mathrm{O}\end{array}$ & $\mathbf{N}$ & $\mathbf{P}_{2} \mathbf{O}_{5}$ & $\mathbf{K}_{2} \mathbf{O}$ \\
\hline 250.00 & 15.00 & 110.00 & 95.62 & 69.40 & 81.81 & 86.43 & 65.01 & 71.61 & 9.61 & 6.33 & 12.47 \\
\hline 260.00 & 17.00 & 120.00 & 86.07 & 67.00 & 76.02 & 76.88 & 62.61 & 65.82 & 10.68 & 6.55 & 13.42 \\
\hline 280.00 & 19.00 & 125.00 & 66.97 & 64.60 & 73.12 & 57.78 & 60.21 & 62.92 & 13.72 & 6.80 & 13.95 \\
\hline 290.00 & 21.00 & 130.00 & 57.42 & 62.20 & 70.22 & 48.23 & 57.81 & 60.03 & 16.00 & 7.06 & 14.51 \\
\hline 300.00 & 23.00 & 140.00 & 47.87 & 59.80 & 64.43 & 38.68 & 55.40 & 54.23 & 19.20 & 7.36 & 15.83 \\
\hline 320.00 & 25.00 & 150.00 & 28.77 & 57.40 & 58.64 & 19.58 & 53.00 & 48.44 & 31.94 & 7.67 & 17.39 \\
\hline 340.00 & 30.00 & 160.00 & 9.67 & 51.39 & 52.84 & 0.48 & 47.00 & 42.64 & 95.04 & 8.54 & 19.30 \\
\hline 400.00 & 32.00 & 170.00 & & 48.99 & 47.05 & & 44.60 & 36.85 & & 8.96 & 21.68 \\
\hline 440.00 & 35.00 & 180.00 & & 45.39 & 41.26 & & 41.00 & 31.06 & & 9.67 & 24.72 \\
\hline 480.00 & 38.00 & 200.00 & & 41.79 & 29.67 & & 37.40 & 19.47 & & 10.50 & 34.38 \\
\hline 520.00 & 41.00 & 220.00 & & 38.19 & 18.08 & & 33.79 & 7.88 & & 11.52 & 56.42 \\
\hline 560.00 & 44.00 & 240.00 & & 34.58 & 6.49 & & 30.19 & & & 12.70 & \\
\hline \multirow[t]{7}{*}{600.00} & 46.00 & 260.00 & & 32.18 & & & 27.79 & & & 13.64 & \\
\hline & 47.00 & 280.00 & & 30.98 & & & 26.59 & & & 14.17 & \\
\hline & 50.00 & 300.00 & & 27.38 & & & 22.99 & & & 16.03 & \\
\hline & 52.00 & 320.00 & & 24.98 & & & 20.59 & & & 17.57 & \\
\hline & 54.00 & 340.00 & & 22.58 & & & 18.18 & & & 19.49 & \\
\hline & 58.00 & 440.00 & & 17.78 & & & 13.38 & & & 24.75 & \\
\hline & 62.00 & & & 12.97 & & & 8.58 & & & 33.85 & \\
\hline \multicolumn{12}{|c|}{ o increase or decrease the yield target by one $\mathrm{q} \mathrm{ha}^{-1}$, the variations to be made in the fertilizer recommendations are as follows } \\
\hline
\end{tabular}


NPK alone - Inorganic equation

2008-09

F.N $=9.128239 \mathrm{~T}-0.678209 \mathrm{STV}\left(\mathrm{KMnO}_{4}{ }^{-}\right.$ N)

F. $\mathrm{P}_{2} \mathrm{O}_{5}=1.603342 \mathrm{~T}-0.342016$ STV (Bray's $\mathrm{P}_{2} \mathrm{O}_{5}$ )

F. $\mathrm{K}_{2} \mathrm{O}=2.329544 \mathrm{~T}-0.174945 \mathrm{STV}$ (Am. Ac. $\mathrm{K}_{2} \mathrm{O}$ )

2011-12

F.N $=9.55311 \mathrm{~T}-0.954963 \mathrm{STV}\left(\mathrm{KMnO}_{4}-\mathrm{N}\right)$

F.P $\mathrm{P}_{2} \mathrm{O}_{5}=2.49750 \mathrm{~T}-1.200641 \mathrm{STV}$ (Bray's)

F. $\mathrm{K}_{2} \mathrm{O}=4.15833 \mathrm{~T}-0.579362 \mathrm{STV}$ (Am. Ace.)

Where, $\mathrm{FN}, \mathrm{FP}_{2} \mathrm{O}_{5}$ and $\mathrm{FK}_{2} \mathrm{O}$ are fertilizer $\mathrm{N}$, $\mathrm{P}_{2} \mathrm{O}_{5}$ and $\mathrm{K}_{2} \mathrm{O}$ in kg ha ${ }^{-1}$, respectively; $\mathrm{T}$ is the yield target in $\mathrm{q} \mathrm{ha}{ }^{-1}$; $\mathrm{SN}, \mathrm{SP}$ and $\mathrm{SK}$ respectively are alkaline $\mathrm{KMnO}_{4}-\mathrm{N}$, Bray's$\mathrm{P}_{2} \mathrm{O}_{5}$ and $\mathrm{NH}_{4} \mathrm{OAc}-\mathrm{K}$ in $\mathrm{kg} \mathrm{ha}^{-1}$ and $\mathrm{OM}-$ organic matter or FYM in $\mathrm{kg} \mathrm{ha}^{-1}$.

Fertilizer response is denoted by the functional relationship between increase in crop yield and added fertilizers. It can be expressed graphically or algebraically by an equation. Milap Chand et al., (2006) reported the superiority of the targeted yield concept over other approaches of fertilizer prescription for different crops as it gave higher yields, net benefit and optimal economic returns. Kasthuri and Natesan (2009) documented the formulation of fertilizer prescription equation for cauliflower crops through STCR targeted yield approach. The yield targets were achieved within reasonable limits when the fertilizer was applied on soil test basis in majority of the crops thus establishing the utility of the prescription equations for recommending soil test based fertilizer application to the farmers. In the present investigation, soil test based fertilizer prescription equations for desired yield target of finger millet was developed using the basic parameters obtained. The data clearly revealed that the fertilizer $\mathrm{N}, \mathrm{P}_{2} \mathrm{O}_{5}$ and $\mathrm{K}_{2} \mathrm{O}$ requirements decreased with increase in soil test values and increased with increase in yield targets.

Fertilizer prescription under IPNS for desired yield target of dry land finger millet

A ready reckoner (Table 5) was prepared using these equations for a range of soil test values and for a yield target of $35 \mathrm{q} \mathrm{ha}^{-1}$ for finger millet. For achieving a yield target of $35 \mathrm{q} \mathrm{ha}^{-1}$ of grain yield of finger millet with a soil test value of 250,21 and $240 \mathrm{~kg} \mathrm{ha}^{-1}$ of $\mathrm{KMnO}_{4}-\mathrm{N}$, Bray's- $\mathrm{P}_{2} \mathrm{O}_{5}$ and $\mathrm{NH}_{4} \mathrm{OAc}-\mathrm{K}_{2} \mathrm{O}$, the fertilizer $\mathrm{N}, \mathrm{P}_{2} \mathrm{O}_{5}$ and $\mathrm{K}_{2} \mathrm{O}$ doses required are $95.62,62.20$ and $6.49 \mathrm{~kg} \mathrm{ha}^{-1}$, respectively under NPK alone and 86.43, 57.81 and $0.0 \mathrm{~kg}$ $\mathrm{ha}^{-1}$ under IPNS approach, where FYM was applied @7.5 t ha ${ }^{-1}$ along with NPK fertilizers. Under IPNS, the fertilizer savings were 9.61, 7.06 and 56.42 per cent respectively when FYM was applied @7.5 t $\mathrm{ha}^{-1}$ along with NPK fertilizers. To increase additional one quintal $\left(35+1 \mathrm{q} \mathrm{ha}^{-1}\right)$ of grain yield, the variation in nutrients application to be made as $9.55 \mathrm{~kg} \mathrm{~N} \mathrm{ha}^{-1}, 2.50 \mathrm{~kg} \mathrm{P}_{2} \mathrm{O}_{5} \mathrm{ha}^{-1}$ and $4.16 \mathrm{~kg} \mathrm{~K}_{2} \mathrm{O} \mathrm{ha}^{-1}$. To decreases the one quintal of grain yield same above values substituted should be from actual nutrient values.

In the present investigation, there was a marked response to the application of NPK fertilizers. The magnitude of response was higher under IPNS approach as compared to inorganics (NPK) alone. The per cent reduction in NPK fertilizers under IPNS also increased with increasing soil fertility levels with reference to NPK. This could be achieved by integrated use of FYM with NPK 
fertilizers. The role of FYM is multidimensional ranging from building up of organic matter, maintaining favourable soil physical properties and balanced supply of nutrients. Therefore, in the present study, soil test based fertilizer prescription for dry land finger millet was developed for Alfisol of Karnataka taking into account of the above factors which might have contributed for the yield enhancement in finger millet when NPK fertilizers were coupled with FYM.

\section{References}

Babalad, H. B., 1999. Integrated nutrient management in soybean based cropping systems. Ph.d. Thesis, University of Agricultural Sciences, Dharwad, Karnataka (India).

Ellis, B. G., Ellis, C. J., Knauss, F. W., Smith, 1956. Nutrient content of corn as related to fertilizer application and soil fertility. Agronomy journal 48(10), 455-459.

Jackson, M. L.1973. Soil chemical analysis, prentice hall of India, Pvt. Ltd., New Delhi, pp. 498.

KasthuriThilagam, V. andNatesan, R., 2009. Fertilizer prescription equations for desired yield targets of cauliflower under integrated plant nutrient system based on targeted yield model.AgricSci Dig., 29(4), 250-3.

Lindsay, W. L. and Norwell, W. A. 1978. Development of DTPA soil test for Zn, Fe, Mnand Cu. J. Soil sci. Soc. Am. 42: 421-428.

Meena, A.M., Raizuddinahmed, S., Chandrasekhara Reddy., Prasad and Rao, B.R.C., 2001. Soil test crop response calibration studies on onion (Allium cepa) in Alfisols. J. Indian Soc. Soil Sci., 49 (4): 709-713.

Milap Chand, D.K. Benbi, D.S. Benipal,2006.Fertilizer

recommendations based on soil tests for yield targets of mustard and rapeseedand their validations under farmer's field conditions in punjab. $J$. Indian. Soc. Soil Sci., 54(3):316-321.

Ramamoorthy, B., Narasimhan, R.L.and Dinesh, R.S., 1967. Fertilizer application for specific yield targets of sonara-64. Indian farming, 5: 43-45.

Ray, P. K., Jana, A. K., Mitra, D. N., Saha, M. N., Chaudhary, J., Saha, S. and Saha, A. R., 2000. Fertilizer prescription on soil test basis for jute, rice and wheat in a TypicUstochrept.J. Indian. Soc. Soil Sci., 48: 79-84.

Praveena Katharine, S., Santhi, R., Maragatham, S. Natesan, R. Ravikumar, V.and PradipDey, 2013. Soil test based fertilizer prescriptions through inductive cum targeted yield model for transgenic cotton on Inceptisol. J. Agri. Veter. Sci., 6(5):36-44.

Saranya, S., Santhi, R., Appavu, K. and Rajamani, K. 2012. Soil test based integrated plant nutrition system for Ashwagandhaon Inceptisols. Indian J. Agri.Res., 46, 88-90.

Santhi, R., A. Bhaskaran and R. Natesan. 2011. Integrated fertilizer prescriptions for beetroot through inductive cum targeted yield model on an Alfisol. Commun. Soil Sci. Pl. Analy., 42: 1- 8.

Santhi,R., Natesan, R. and Selvakumari,G., 2002. Soil test crop response correlation studies under integrated plant nutrition system for onion (Allium cepa Var. Aggregatum) in Inceptisolof Tamil Nadu. J. Indian Soc. Sci., 50(4): 489492.

Singh, S. P., Gour, B. L., Shetty Hawal, 1992. Effect of cultivar spacing and nitrogen fertilization on yield and nutrient uptake by maize. Annual Agri. Res., 13, 277279

Smitha John, K., Santhi, R. MurugesaBoopathi, P. Natesan R. and Gayathri. A. 2010. Soil test based fertiliser prescription under integrated 
plant nutrition system for cabbage on Inceptisolof Tamil Nadu. Ad. Plant sci., 23 (1):155-157.

Subbaiah, B. V. and Asija, G. L. 1956. A rapid procedure for the estimation of available nitrogen in soils. Curr. Sci. 25:259-260.

Thamaraiselvi, T., Brindha, S., Kaviyarasi, N. S., Annadurai, B. and Gangwar, S. K., 2012. Effect of organic amendments on the bio chemical transformations under different soil conditions. International J. Ad. Bio. Res., 2(1): 171-173.

Uma Devi, R.2005. Soil test crop response correlation studies under integrated plant nutrition system for carrot on Alfisols. M.sc (Agri) thesis submitted to Tamil Nadu Agricultural University, Tamil Nadu, India.

VelayuthamM, Reddy K.C.K and Maruthi SankarG.R, 1976, an experimental evaluation of soil testing for fertilizer recommendation under the multiple cropping. ILRIS, 25: 185-190.

Vijayalakshmi, K., 2008. Soil test crop response studies on radish under integrated plant nutrition system. M.Sc. (Agri.) Thesis, TNAU, Tamil Nadu, India.

\section{How to cite this article:}

Basavaraja, P.K., H. Mohamed Saqeebulla and Dey, P. 2017. Integrated Fertilizer Prescription Equations for Finger Millet (Eleusine coracana L.) Through Inductive Cum Targeted Yield Model on an Alfisol. Int.J.Curr.Microbiol.App.Sci. 6(7): 2571-2580. doi: https://doi.org/10.20546/ijcmas.2017.607.363 